University at Albany, State University of New York

Scholars Archive

$1-2015$

\title{
Demarcating Aristotelian Rhetoric: Rhetoric, the Subalternate Sciences, and Boundary Crossing
}

Marcus P. Adams

University at Albany, State University of New York, madams2@albany.edu

Follow this and additional works at: https://scholarsarchive.library.albany.edu/cas_philosophy_scholar

Part of the Philosophy Commons

\section{Recommended Citation}

Adams, Marcus P., "Demarcating Aristotelian Rhetoric: Rhetoric, the Subalternate Sciences, and Boundary Crossing" (2015). Philosophy Faculty Scholarship. 43.

https://scholarsarchive.library.albany.edu/cas_philosophy_scholar/43

This Article is brought to you for free and open access by the Philosophy at Scholars Archive. It has been accepted for inclusion in Philosophy Faculty Scholarship by an authorized administrator of Scholars Archive. For more information, please contact scholarsarchive@albany.edu. 


\title{
Marcus P. Adams
}

\section{Demarcating Aristotelian Rhetoric: Rhetoric, the Subalternate Sciences, and Boundary Crossing}

\begin{abstract}
The ways in which the Aristotelian sciences are related to each other has been discussed in the literature, with some focus on the subalternate sciences. While it is acknowledged that Aristotle, and Plato as well, was concerned as well with how the arts were related to one another, less attention has been paid to Aristotle's views on relationships among the arts. In this paper, I argue that Aristotle's account of the subalternate sciences helps shed light on how Aristotle saw the art of rhetoric relating to dialectic and politics. Initial motivation for comparing rhetoric with the subalternate sciences is Aristotle's use of the language of boundary transgression, germane to the Posterior Analytics, when discussing rhetoric's boundaries, as well as the language of "over" and "under" found in APo. First, I discuss three passages in Rhetoric Book I and argue that Garver's (1988) account cannot be correct. Second, I look to the subalternate sciences, especially focusing on optics and the distinction between "unqualified" optics and mathematical optics. Third, I discuss rhetoric's dependence on both dialectic and politics.
\end{abstract}

Keywords: Aristotle, Rhetoric, Dialectic, Politics, Subalternate Science

\section{Introduction}

The ways in which Aristotelian sciences are related to each other has been discussed in the literature, with some focus on the subalternate sciences such as optics, harmonics, mechanics, and astronomy (e.g., Lennox 1986; McKirahan 1978). While it is acknowledged that Aristotle, and Plato as well, was concerned with how the arts ( $\tau \dot{\chi} \chi v \alpha \iota)$ were related to one another (McKirahan 1978, 197198), less attention has been paid to Aristotle's views on relationships among

Marcus P. Adams: University at Albany - Philosophy, Humanities 257, 1400 Washington Avenue, Albany, New York 12222, United States, E-Mail: marcuspadams@gmail.com 
the arts. On such relationships, John Cooper (1975, 14-15) has argued that some arts like rhetoric are subordinate to others like statesmanship, because the latter use the results of the former as a means (likewise McKirahan 1978, 197). Although Cooper correctly identifies Aristotle's claim that rhetoric is "under" politics, or statesmanship, (see EN 1094b2-5), this is not all Aristotle has to say about the relationship between rhetoric, dialectic, and politics.

In this paper, I argue that Aristotle's account of the subalternate sciences will help shed light on how Aristotle saw the art of rhetoric relating to dialectic and to politics; for both, rhetoric is said to be an offshoot (1356a22-35). Specifically, I argue that Aristotle's discussion of whether there are two or three distinct sciences involved in the subordinate relationship (cf. Lennox 1986, 46-47) will be useful to compare to what Aristotle says about rhetoric. I also argue that Garver's (1988) interpretation of the boundary around rhetoric cannot be correct and, if it were correct, would commit Aristotle to views that we find in the Gorgias that criticize rhetoric's status.

Initial motivation for comparing rhetoric with the subalternate sciences is Aristotle's use of the language of boundary transgression that is germane to the Posterior Analytics ( $\mu \varepsilon \tau \alpha \beta \alpha$ เvعĩv) when discussing rhetoric's boundaries, as well as the language of "over" and "under" that one finds in APo. I will argue that Aristotle does not see these arts on the same model as the subalternate sciences; nonetheless, it will be useful to consider his discussion of the number of distinct sciences that are involved with subalternate science explanations. First, I discuss three passages in Book I of the Rhetoric that relate to rhetoric's boundary and argue that Garver's (1988) account cannot be correct. Second, I look to the subalternate sciences, especially focusing on optics and the distinction between "unqualified" optics and mathematical optics. Third, I discuss rhetoric's dependence on both dialectic and politics. Highlighting these features of rhetoric and its relationship to both dialectic and politics will show that Cooper's and McKirahan's account of the relationship does not appreciate the complex ways in which the offshoot, rhetoric, is related to dialectic and politics.

\section{A Problem with Boundaries}

In three passages in Book I of the Rhetoric, Aristotle is concerned with demarcating rhetoric's boundary from other disciplines, such as dialectic. These passages have attracted some attention in the literature because they discuss not only how one may transgress the boundary around rhetoric and enter into an- 
other discipline (Rhet I.2.19-22, 1358a1-30) but also because they speak about the disciplines to which rhetoric is intimately related. Aristotle describes rheto-

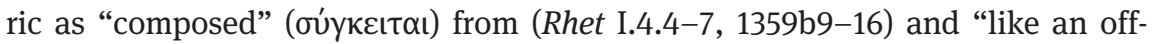

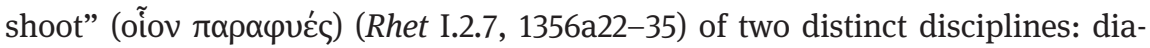

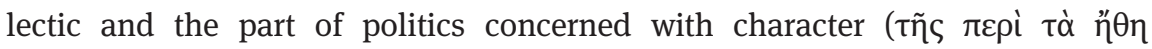

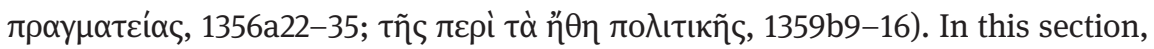
I first provide these passages and then outline and criticize Eugene Garver's account of rhetoric's boundary.

Before discussing these passages, it may be useful to discuss one of Aristotle's primary goals in the Rhetoric. This goal is to provide an account of the

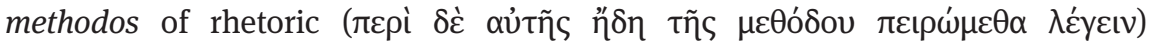

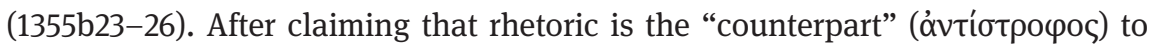
dialectic (1354a1), Aristotle notes that all people have a share in both of them

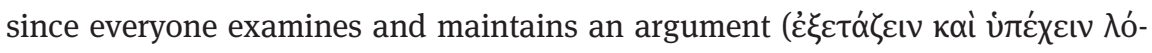
yov), i.e., the activities relating to dialectic, and everyone defends and accuses

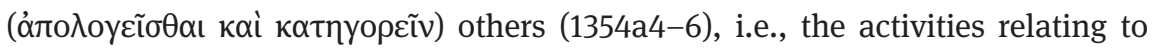
rhetoric. Everyday people without training in rhetoric who engage in these ac-

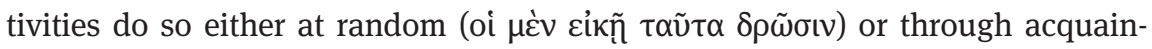

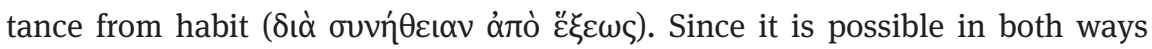

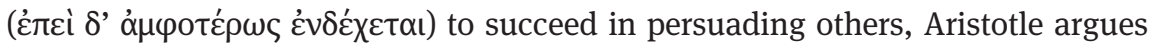
that it is clear that a method-or more closely to the Greek, a way-can be pro-

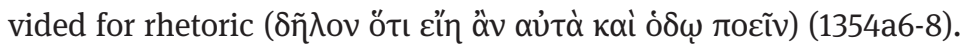

Part of providing the methodos of rhetoric involves discovering and explicating the cause of persuasion. Aristotle claims that it is possible to observe the

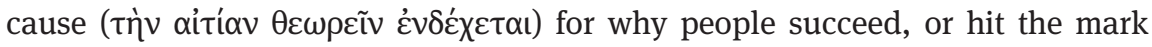

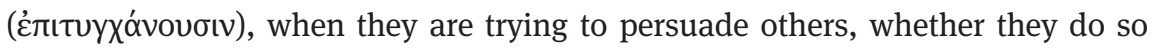

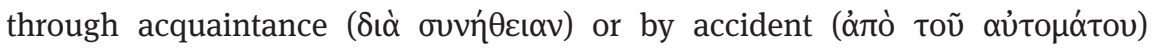
(1354a9-11). That the Rhetoric is concerned with the cause of persuasion is clear from Aristotle's later discussion of the differences between example and the enthymeme, both of which he claims are equally persuasive but the latter of which

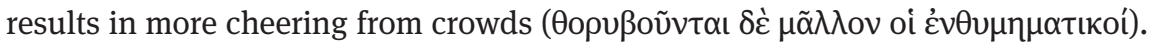
The cause of these two being equally persuasive and of enthymemes resulting

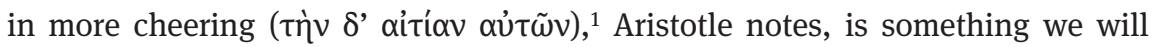

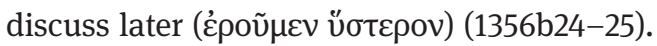

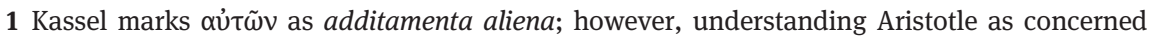
both with the cause of the two being equally persuasive and enthymemes resulting in more cheering is a natural reading of the passage (and others read the passage this way, e.g., Kennedy 1991, 29). Aristotle discusses this later in Book II.20-24. 
An important distinction that Aristotle seems to make is between rhetoric qua faculty that authors write about and students learn and rhetoric qua practice. The work or function of rhetoric qua faculty is not merely to persuade (ö $\tau$

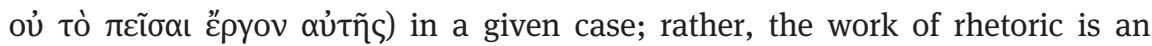

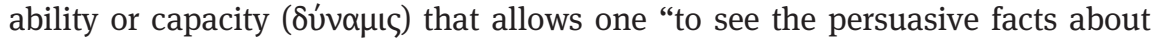

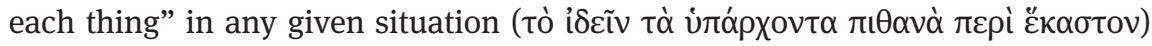
(1355b9-11). ${ }^{2}$ The work of rhetoric qua practice is concerned with proofs (pisteis), which are "the only things within the province of the art; everything else [which the other writers on rhetoric have given us] is an appendage (prosthekai) ...enthymemes are the $\sigma \tilde{\omega} \mu \alpha \tau \tilde{\eta} \varsigma ~ \pi ı \sigma \tau \varepsilon \dot{ } \omega \varsigma$ ” (on this last point, see Burnyeat 1994, 10-13). I will return to this distinction between rhetoric qua faculty and rhetoric qua practice throughout the paper.

\title{
2.1 Boundary Passages in the Rhetoric
}

In the first relevant passage, Aristotle discusses the person who will be an effective rhetorician. This individual, he notes, must be skilled in logical reasoning, know how to perceive people's characters and virtues, and also know a great deal about emotions, as the following extended quotation illustrates:

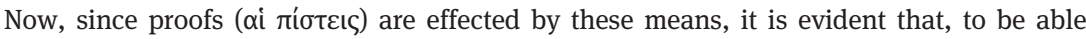

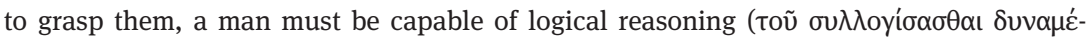

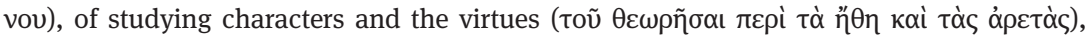
and thirdly the emotions ( $\pi \dot{\alpha} \theta \eta$ ) - the nature and character of each, its origin, and the manner in which it is produced. Thus, it appears that rhetoric is as it were an offshoot

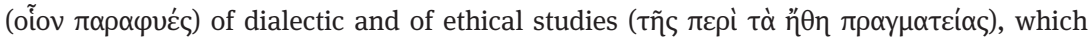
may be reasonably called political ( ter of politics, and those who claim to possess it, partly from ignorance, partly from boastfulness, and partly from other human weaknesses, do the same. For, as we said at the outset, rhetoric is a sort of division or likeness of dialectic, since neither of them is a science that deals with the nature of any definite subject, but they are merely faculties

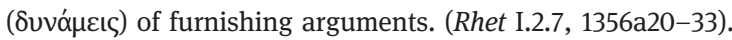

In the context immediately preceding this passage, Aristotle has just distinguished between three kinds of proofs that a rhetorician employs when speaking: the first depends on the speaker's character; the second on how the speaker

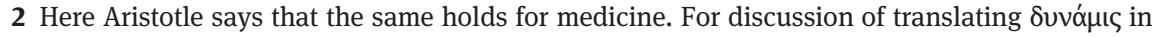
the Rhetoric, see Haskins (2013). Kennedy (Aristotle 1991) renders it as "ability," while Freese (Aristotle 1926) and Barnes (Aristotle 1984) use "faculty." Barnes also sometimes uses "practical faculty" (cf. Arisotle 1984, 2161; 1359b12). 
places the hearer in a certain "frame of mind"; and the third on the speech itself, that is, what it seeks to demonstrate (1356a1-4). Aristotle's comment on the relationship between rhetoric, dialectic, and the part of politics concerned with character is of most interest for the present topic. Rhetoric should be viewed as an "offshoot" of these two disciplines because of the diverse types of things that a skillful rhetorician must know as a practitioner of rhetoric.

The second relevant passage has attracted the most attention of the three in the literature concerned with the demarcation of rhetoric from other disciplines. Garver (1988) focuses upon this passage and the final passage.

But a very great difference between enthymemes has escaped the notice of nearly every one, although it also exists in the dialectical method of syllogisms. For some of them belong to rhetoric, some syllogisms only to dialectic, and others to other arts and faculties, some already existing and others not yet established. Therefore these individuals fail to notice this difference, and the more they fasten upon the subject matter in its

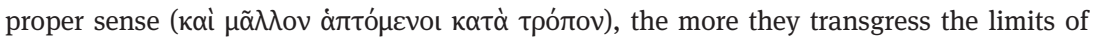
rhetoric and dialectic $(\mu \varepsilon \tau \alpha \beta \alpha i ́ v 0 v \sigma v v \dot{\varepsilon} \xi \alpha \dot{\tau} \tau \tilde{\omega} v){ }^{3}$ But this will be clearer if stated at greater length.

I mean by dialectical and rhetorical syllogisms those which are concerned with what we call "topics," which may be applied alike to questions relating to the right, physics, politics, and many other things that differ in kind, such as the topic of the more or less, which will furnish syllogisms and enthymemes equally well for questions relating to the right, physics, or any other science whatever, although these subjects differ in kind. Specific topics on the other hand are derived from propositions which are peculiar to each species or genus of things; there are, for example, propositions about physics which can furnish neither enthymemes nor syllogisms about ethics, and there are propositions concerned with ethics which will be useless for furnishing conclusions about physics; and the same holds good in all cases. The first kind of topics will not make a man practically wise about any particular class of things, because they do not deal with any particular subject matter; but as to the specific topics, the happier a man is in his choice of propo-

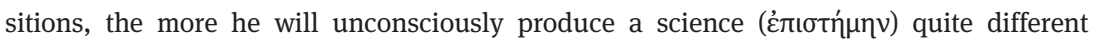

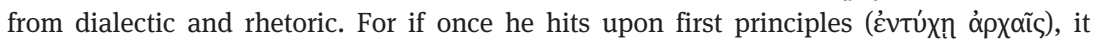
will no longer be dialectic or rhetoric, but that science whose principles he has arrived

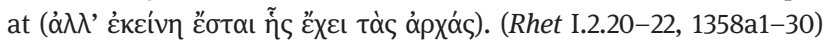

There is much going on in this passage, but a few relevant points will become clearer when I discuss Garver's (1988) interpretation of this and the next pas-

3 I have adapted Grimaldi's (1980a, 73) translation to deal with a minor textual matter. Kassel (1976) suggests that 1358a8-9 is corrupted (orationem mancam significavi) and includes "the

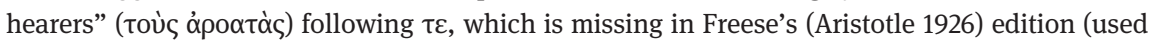
by Garver 1988). Furthermore, Kassell (1976) argues that there is a lacuna in 1358a8 following

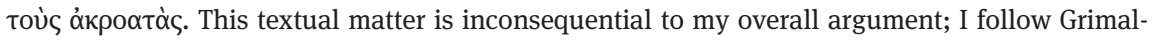
di (1980a) here and below. 
sage. A key phrase singled out by most who are concerned with interpreting this passage is "the more they specialize in a subject, the more they transgress the limits of rhetoric and dialectic." I will argue below that Aristotle is concerned with the way that a rhetorician treats facts from politics when he is making a speech, i.e., that the rhetorician cannot treat facts from political science in his speeches in the same way he would if he were engaging in political science. In other words, I will argue that Aristotle is concerned at this point with rhetoric qua practice.

The third relevant passage is contained within Aristotle's discussion of deliberative rhetoric, where he is concerned with "what kind of good and bad things the deliberative orator advises" (Rhet I.4, 1359a37ff). Although it is part of a discussion focused on one of the three kinds of rhetoric (i.e., deliberative, forensic, and epideictic; see Rhet I.3, 1358b7-9), what he says is about rhetoric in general since he seems to identify it as a summary of what he has already

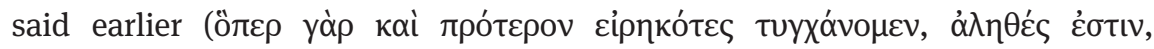
1359b8-9), though he does provide a slightly different account than the passage immediately above:

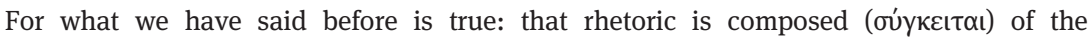

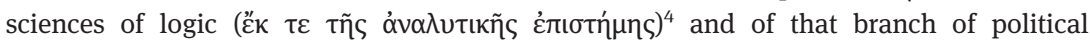

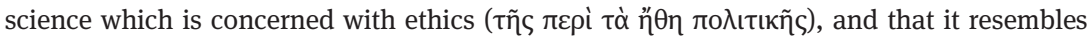
partly dialectic and partly sophistical arguments. But in proportion as anyone endeavors

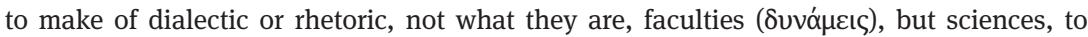
that extent he will, without knowing it, destroy their real nature, in thus altering their character, by crossing over ( $\mu \varepsilon \tau \alpha \beta \alpha i ́ v \varepsilon ı v)$ into the domain of sciences, whose subjects are

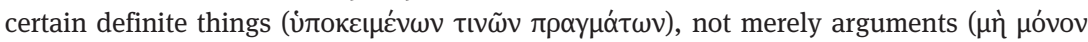

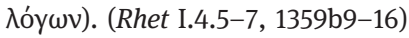

The key points in this passage and the preceding one that will be relevant to the discussion at hand are Aristotle's description of rhetoric's relationship to dialectic and the part of politics concerned with character, i.e., "composed of" and "offshoot of", and Aristotle's description of crossing ( $\mu \varepsilon \tau \alpha \beta \alpha i v \varepsilon v$ ) the boundary from rhetoric into another discipline.

I take it that we should understand Aristotle's claim that the subject of rhetoric is "merely arguments" in 1359b16 as referring to rhetoric qua what people who write handbooks of rhetoric focus upon and what students learning rhetoric focus upon. That is, when learning how to be a skillful rhetorician from a handbook, one does not learn facts from political science. Instead, one learns ways of arguing and what types of emotions to appeal to in speeches. This is how one acquires the

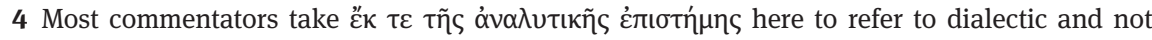
the Analytics. 
faculty of rhetoric whereby one can see which facts are persuasive and which aren't; such a faculty, however, is not acquired by learning facts from politics or some other science. Others focusing on this passage, e.g., Garver (1988), have taken the phrase "merely arguments" to refer to the practice of rhetoric, which presents a number of problems for understanding what the practice of Aristotelian rhetoric would look like, as I will outline in the next section. ${ }^{5}$

\subsection{Garver's Account of Crossing Rhetoric's Boundary}

Before discussing the passages provided above and Garver's interpretation of them, it is first important to differentiate the present discussion from an ongoing discussion in the literature about Aristotelian rhetoric. This different, but related debate concerns whether rhetoric is a moral activity. The question under debate in this literature is whether there is an "essential linkage between [Aristotle's] ethics and rhetoric" (Johnstone 1980, 1; see also Rowland \& Womack 1985). Many have argued, strangely, that for Aristotle the two are completely disconnected and that rhetoric is concerned only with persuasion (see Johnstone 1980, n. 2 for examples). Though an important debate, this is an ancillary issue to the topic of the present paper since the answer one gives to that question does not decide the debate over whether Aristotle viewed rhetoric as a separate investigation from dialectic and politics. That is, one could think that Aristotle viewed rhetoric as a moral activity while also thinking that he took it to be an independent investigation from dialectic and politics.

One of Garver's primary goals is to explain how rhetoric is different from other disciplines. Specifically, he highlights the following claims: first, that the more one specializes in a particular subject the more one transgresses "the limits of rhetoric and dialectic" (1358a9-10); and second, that when one tries to

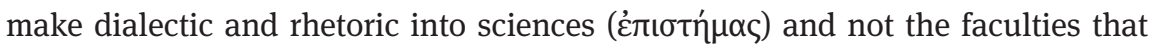
they are, one crosses over rhetoric's boundary into the sciences, where the subjects are "certain definite things (ن่

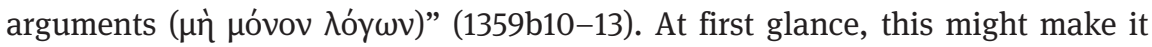
seem that the person who follows Aristotle's guidance in the Rhetoric will in his practice of rhetoric actively avoid having specialized knowledge and focus, instead, only upon the types of arguments that one might use to persuade people.

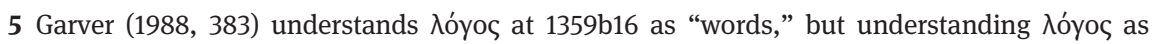
"arguments" seems more natural given the explicit connection in this passage, and elsewhere, between dialectic and rhetoric. I thank an anonymous referee of this journal for emphasizing this. 
What exactly focusing only upon arguments that would be persuasive to the exclusion of any specialized knowledge (e.g., knowledge of the state of the polis in which one is speaking) would look like when practicing rhetoric (i.e., when giving a speech) is one question, the answer of which is unclear to me. Whether this is Aristotle's account is another. With regard to this second question, I will argue that this is not Aristotle's view. Garver, however, argues that this is how we should understand Aristotle's account of the boundary of rhetoric, as the following quotation illustrates:

In rhetoric one tries to make one's discourse more and more secure from refutation, tries to make the audience's assent to one's arguments as close to compulsory as possible, but to succeed fully is to cease being rhetorical [...] $(1988,390)$.

Garver calls this account one of "self-destructive success” (1988, 390). Garver's point, were it correct, would place Aristotelian rhetoric on a paradoxical foundation. That is, to succeed, for example, as a deliberative rhetorician one must on the one hand know facts from the science of politics relating to the situation about which one will be speaking (as Aristotle admits and will be discussed below; see 1360a36-37) while on the other hand, on Garver's (1988) interpretation the more one learns about that situation the more what one is doing will "cease being rhetorical." 6 Garver is not alone in this interpretation. James Allen argues that rhetoric (and here also dialectic) proceeds without "substantive specialized understanding" and that insofar as one "draws on such understanding, one leaves behind dialectic [and rhetoric]" (Allen 2007, 97).

Beyond the difficulty this interpretation has with other passages in the Rhetoric and with the conceptual strangeness of saying that the best sort of rhetorician should know fewer facts and not more, Garver's interpretation is quite similar to a view advanced against rhetoric in the Gorgias. Aristotle would reject any such identification, so briefly examining a few of the relevant passages in the Gorgias will be worthwhile to see where Garver's interpretation goes astray.

Rather than advocating Aristotle's view described above, where rhetoric is an "offshoot" or "composed" of a part of politics, Socrates argues that "rhetoric is ...the unreal image (counterfeit presentment) of a branch of politics" (463d) ( $\dot{\eta}$

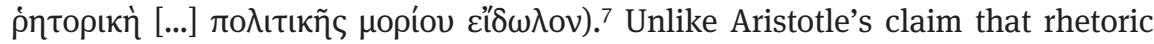
is the "counterpart" ('́)

6 Strangely, the passage where Aristotle discusses the numerous things the successful deliberative orator must know (1359b19ff) immediately follows the main passage from which Garver (1988) derives this interpretation, but Garver does not mention this passage in articulating his view.

7 English references to the Gorgias are to Plato (1998) and Greek are to Plato (1990). 
rhetoric is the counterpart to cookery, as the following quotation illustrates: “...

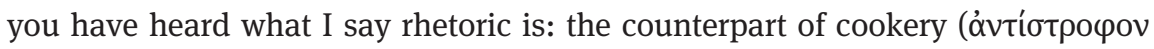
о $\psi о \pi о$ í $\alpha$ ) in the soul, as that [is the counterpart of rhetoric] in the body" (465d). Cookery, he notes, “...has slipped in under medicine and pretends to know the best foods for the body...” (464d). Socrates' full account of the various counterparts he is discussing is something that he provides "as the geometers"

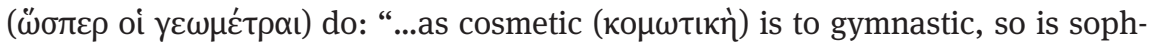
istry to the legislative art; and as cookery is to medicine, so rhetoric is to justice" (465c).

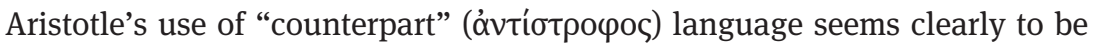
a response to Plato's attack on rhetoric (as Roberts 1924, 345 notes), but Aristotle also responds, I will argue later, to one of the primary reasons behind Plato's claim that rhetoric is the counterpart to cookery. ${ }^{8}$ Rhetoric is the counterpart to cookery, Socrates argues, because those who practice rhetoric not only can be wholly ignorant of facts, but moreover the ignorant person is more persuasive than the expert. This claim comes out of the discussion Socrates and Gorgias have regarding whether the knowledgeable physician will be able to persuade a crowd better than the ignorant individual.

A contrast at work in the background of their discussion of the physician and the ignorant person is between convincing a crowd by means of instruction and doing so by means of persuasion. The ignorant individual is more persuasive, Socrates and Gorgias both agree, because he convinces the crowd "not by

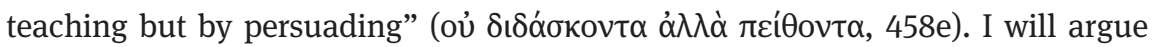
later that on Aristotle's account this is a false dichotomy. From this discussion with Gorgias, Socrates concludes:

So then is the rhetor, and rhetoric, in the same situation in regard to all the other arts as well? It does not at all need to know how the matters themselves stand, but to have discovered a certain device of persuasion so as to appear to know more than those who know, to those who don't know (459b-c).

8 There is a long tradition of interpretation on how we should take Aristotle's claim that rhetoric is the "counterpart" to dialectic. Beyond most interpreters agreeing that it is a reference to Plato's argument that rhetoric is the counterpart to cookery, there have been various other suggestions. One 16th century commentator, John Rainold, notes that "There are as many interpretations of this little word as there are interpreters" (cited in Green 1990, 7). Two of the most popular interpretations of the term are that it relates either to the relationship between the strophe and the antistrophe in Greek choruses (see Green 1990, 8) or to Aristotle's extensive use

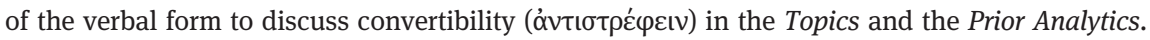
Green $(1990,9)$ notes that Aristotle uses various forms of the verb over 150 times in these two texts. 
Aristotle cannot hold such a view given his claim that rhetoric is the counterpart to dialectic. But this view has noticeable similarities to Garver's (1988) interpretation that I detailed above. On Garver's account, one is no longer within the confines of rhetoric when one learns facts about the situation about which one is to speak. On Garver's account, and likewise on Plato's account, the ignorant individual is more persuasive than the expert, for all he needs to persuade a crowd is "some instrument of persuasion."

Without speculating on the precise reasons, it seems that some have been forced into a position such as Garver's because they have failed to distinguish two different aspects of rhetoric that Aristotle discusses: rhetoric qua faculty that is written about and learned as a skill and rhetoric qua practice. The two passages that Garver addresses can be handled by carefully looking at which of these two aspects of rhetoric Aristotle is discussing.

The passage at Rhet I.2.20-22 (1358a1-30) that inspires Garver's (1988) view can be dealt with first by looking to Grimaldi's reading of the key sentence in this passage:

Therefore, these individuals fail to notice this difference [between types of syllogisms],

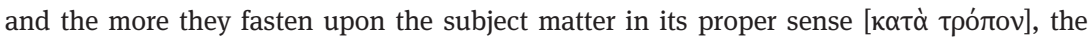
more they shift from the arts of rhetoric and dialectic (Grimaldi 1980a, 73).

On this reading, it is not specializing in a particular subject such as politics that makes a rhetorician cross the boundary from rhetoric into something else. Instead, it is treating that subject matter in a speech as one would within its proper domain - in its proper sense. That is, if one speaks to a crowd about politics as one would speak to a specialist in political science then one has left the practice of rhetoric. ${ }^{9}$ Taking this passage in this way dissolves the tension introduced by Garver. The rhetorician need not be ignorant to be effective; rather, he should treat the facts he gets from sciences, such as politics, and uses in a speech as one should treat them when giving a speech (more on this below); he should not treat them as he would treat them in the discipline of politics.

We can remove the difficulty Garver introduces with the second passage to which he appeals (the third passage in the preceding subsection; Rhet I.4.5-7) by noticing that Aristotle is there talking about the faculty of rhetoric and not the actual practice of it. It seems we can take Aristotle to be talking about what writers of books on rhetoric write and on what students of rhetoric focus when learning rhetoric. People cross over rhetoric's boundary in this sense when they try to make it not a faculty but something that has facts as its subject (1359b9-

9 For discussion regarding treating ката̀ тро́лоv as "using the method proper to the specific discipline,” see Grimaldi’s discussion of 1358a9 (1980a, 73). 
16). But what is the subject of rhetoric qua faculty, then? Arguments, Aristotle

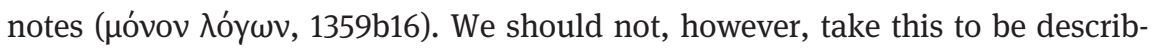
ing the practice of rhetoric, as Garver must for his interpretation to be tempting. Instead, when one writes about rhetoric or works to acquire the faculty of rhetoric, one focuses on types of arguments that are likely to be more persuasive than others. This focus will not be on particular facts, e.g., about a given polis; rather, the focus will be on types of arguments (i.e., enthymemes and examples) that are likely to be persuasive in various situations (this will be discussed more below).

This reading is further supported by Aristotle's claim in the first quotation above (Rhet I.2.7, 1356a33) that the faculties of rhetoric and dialectic are both

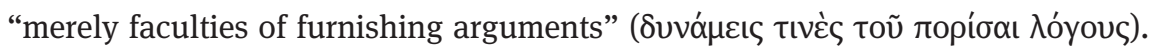
That is, when considered just as faculties that are taught by writers of rhetorical handbooks and acquired by students of rhetoric, rhetoric is concerned just with giving one persuasive arguments, regardless of the subject matter of one's speech. The actual practice of rhetoric, however, must draw upon facts from disciplines such as politics.

\section{The Boundaries of Sciences and Rhetoric}

Initial motivation for examining the subalternate sciences to help illuminate the relationship between rhetoric and dialectic and politics comes from the similar language Aristotle uses to describe leaving the boundaries of one and entering another. ${ }^{10}$ Two similarities in language between Aristotle's discussions of the subalternate sciences and rhetoric are the language of "crossing over" ( $\mu \varepsilon \tau \alpha \beta \alpha$ -

10 One might argue that Aristotle sees crossing the boundary from rhetoric to other disciplines differently from crossing the boundary between, say, geometry and optics because rhetoric is a techne. However, Aristotle includes medicine as an example that is not strictly subalternate but

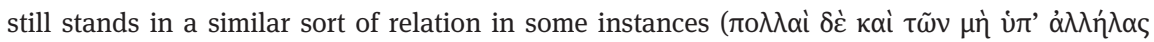

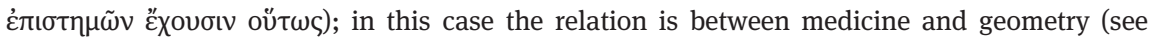
APo 79a13-16). It is for medicine to know that a particular wound heals in a certain way (in this case a circular wound), but it is for the geometer to know the reason why. Rhetoric is, at various points, called a techne along with medicine (e.g., Rhet I.2), and they are both called facul-

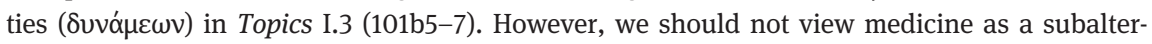
nate science from this example alone, since there will be other facts related to the knowledge of how circular wounds heal, such as that healing occurs from the edges and is not evenly distributed across a wound throughout the healing process. Indeed, there will not be an area of inquiry that is called mathematical medicine, though geometry may be relevant in certain cases (I thank an anonymous reviewer of this journal for emphasizing these points). For further dis- 
veiv) and the language of over and under. ${ }^{11}$ In this section, I will first discuss briefly the status of the subalternate sciences for Aristotle. Next, I will focus on one facet of Aristotle's account of the subalternate sciences relevant to determining how Aristotle views rhetoric's relation to dialectic and politics: the question of how many sciences there are involved in such "borrowing" relationships.

\subsection{The Subalternate Sciences}

Aristotle discusses "crossing over" from one discipline to another in Book I of the Posterior Analytics. ${ }^{12}$ When discussing this at APo I.7, he argues that "it is not possible to prove a fact by passing from one genus to another ( $\dot{\varepsilon} \xi \hat{\alpha} \lambda \lambda$ ov

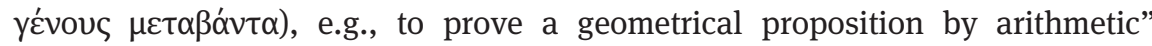
(75a38-39). It is important to note that Aristotle's use of $\mu \varepsilon \tau \alpha \beta \alpha$ sveív here and elsewhere does not seem to have the negative connotations Garver takes it to have, ${ }^{13}$ especially since he uses the same term a few lines later to describe a successful demonstration: "Thus the genus must be the same, either absolutely or in some respect, if the genus is to be transferable ( $\mu \varepsilon \tau \alpha \beta \alpha$ เveiv)" (75b8-10). The last phrase could be rendered more closely to the Greek as "if the demonstration is going to cross," as Jonathan Barnes translates it in the ROT version of $A P o$. Their genera being the same "in some respect" (75b9) characterizes the relationship between the subalternate sciences and the sciences over them.

Continuing in APo I.7, Aristotle states that one cannot "prove by any other science the theorems of a different one, except such as are so related to one

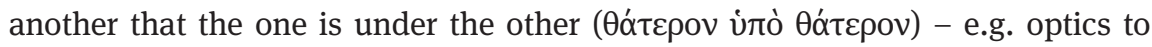

cussion of the subalternate sciences and the connection between medicine and the science of nature, see Lennox (2005, esp. 66-68).

11 Interestingly, a 16th century commentator on Aristotle's Rhetoric, Augustino Nifo, also proposed using subalterna to describe the relationship of rhetoric to dialectic in a work entitled Expositio atque rhetoricae libri tres (1538). For discussion of this point, see Green (1990, 16).

12 Aristotle also discusses the subalternate sciences in Physics II.2, calling them "the more natural of the branches of mathematics" (194a8-9), and in Metaphysics M.1-3, especially at 1078a14-17.

13 Part of the motivation behind Garver's project is trying to figure out the following: "Why does Aristotle regard the movement from rhetorical to scientific argument as a transgression (metabainousin) rather than an achievement?" (Garver 1988, 382). Later Garver also compares the use of "scientific discourse" in rhetoric as analogous to "using the results of torture" (1988, 387). Aristotle's use of the language of "crossing over" in other, similar contexts should remove any motivation for viewing $\mu \varepsilon \tau \alpha \beta \alpha$ เveív with negative connotations. 
geometry and harmonics to arithmetic" (75b14-17). As James Lennox (1986, 3940) notes, Aristotle's focus in APo I.2 and I.9 is on the distinction "between achieving unqualified ( $\dot{\alpha} \pi \lambda \tilde{\omega} \varsigma$ ) or 'universal' understanding and having merely 'incidental' or 'sophistic' understanding of it." In APo I.9, Aristotle explains when we have nonincidental, or universal, understanding:

\begin{abstract}
We understand a thing nonincidentally when we know it in virtue of that according to which it belongs, from the principles of that thing as that thing. For example, we understand something's having angles equal to two right angles when we know that to which it belongs in virtue of itself, from that thing's principles. Hence if that too belongs in virtue of itself to what it belongs to, the middle term must be in the same kind. If this isn't the case it will be as the harmonical properties are known through arithmetic. In one sense such properties are demonstrated in the same way, in another sense differently; for that it is the case is the subject of one science (for the subject-kind is different), while the reason why it is so is of a higher science, of which the per se properties are the subject $(76 a 4-13) .^{14}$
\end{abstract}

Here Aristotle argues that in the case of a science such as harmonics, or optics,

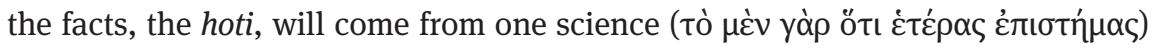
while the reason why, the dioti, will come from a science which is "above" that

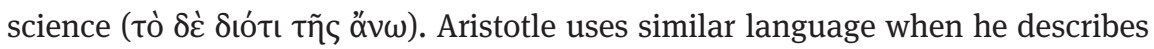

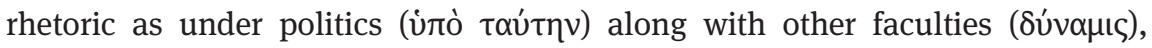
which we might translate also as "capacities," such as the faculties of strategy and domestic economy (EN 1094b2-5). However, even though using similar language about these as being "under" politics, unlike the relationship between geometry and optics the discussion in EN is not concerned with explanations (discussed more below).

\title{
3.2 How Many Sciences?
}

There has been some discussion on the relationship between the subalternate sciences and the higher sciences (e.g., Lennox 1986; McKirahan 1978; Hankinson 2005), but I want to focus on a facet of the debate that is relevant to the question of rhetoric's relation to dialectic and politics. This is the question of whether Aristotle views rhetoric as independent of the disciplines upon which it depends. That is, since rhetoric is dependent upon both dialectic and politics, we might take him as saying that rhetoric is really just a specialized use of dia-

14 I have used Lennox’s translation $(1986,40)$. 
lectic that makes use of facts from politics. On such a view, rhetoric is independent only insofar as it is dialectic used in a different context.

The simple answer to this question related to rhetoric's independence is that we should say it is independent from dialectic and politics because Aristotle chose to write a separate text on it - the Rhetoric. While this may be tempting, what Aristotle says about rhetoric and its relation, e.g., to dialectic, makes such a simplistic explanation difficult. For example, when discussing the two modes

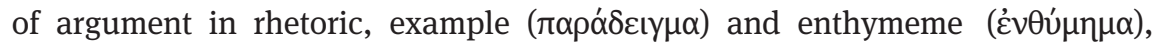
Aristotle explicitly connects these to the two in dialectic, i.e., induction and syllogism. He states: "for example is induction, and the enthymeme a syllogism

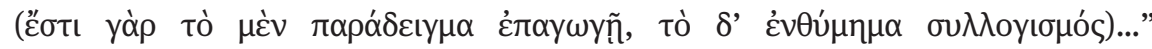
(1356b2-3). The tight connection Aristotle advances between the modes of argument in dialectic and rhetoric discourages the simplistic view.

Likewise, Aristotle's claim already mentioned, that rhetoric is "under" politics in the Nicomachean Ethics (EN 1094b2-5) makes such a simplistic explanation equally difficult. This simplistic view does not answer how we should understand what sort of "under" characterizes this relationship. Furthermore, the simplistic view does not solve the issue of rhetoric's independence because Aristotle may have written a separate text on rhetoric for reasons completely unrelated to his view on the status of rhetoric as a discipline. That is, there was already an existing tradition of rhetorical handbooks, which Aristotle mentions and criticizes early in the text (see Rhet I.1.3, 1354a15ff), so Aristotle's desire to have the Rhetoric as a stand-alone text may reflect more his desire to respond to that tradition than his views on rhetoric's status.

We return to the subalternate sciences. Optics provides an example where Aristotle distinguishes between distinct sciences. Drawing upon Meteorology III.2-6 and APo I.13 (78b10-17), Lennox (1986, 46-47) highlights the distinction that Aristotle makes between "unqualified" ( $\dot{\alpha} \pi \lambda \tilde{\omega} \varsigma)$ optics and mathematical optics. One way of understanding this reference to "unqualified" optics is to see it as related to the study and explanation of optical phenomena generally; the phenomena explained under unqualified optics include both mathematical and physical properties. Mathematical optics, however, is concerned with using principles from pure geometry to a "restricted class of geometrical properties instantiated in the patterns of the optical array" (Lennox 1986, 47). Such explanations in mathematical optics fall under the general domain of unqualified optics, but under unqualified optics there will also be explanations that are only physical, such as the explanation of the type of reflection a rainbow is. For example, when discussing color and light in De Anima II.7 (418a26-419b2), Aristotle appeals only to physical principles (cf. Lindberg 1996, xxxvi). So just as one may talk about the art of rhetoric generally, which would be an umbrella term 
that includes both the areas of rhetoric qua faculty and rhetoric qua practice that I have been discussing, one may also talk about optics generally - optics $\dot{\alpha} \pi \lambda \tilde{\omega} \varsigma$ and refer to mathematical as well as physical optics.

Though my discussion of this issue has been brief, ${ }^{15}$ I think that these considerations of the distinction between geometry, unqualified optics, mathematical optics, and physical optics will help us think about rhetoric and its relationship to dialectic and politics. In the next section, I will suggest that we think of rhetoric generally as analogous in some ways to unqualified optics; as such, rhetoric generally includes both rhetoric qua faculty and rhetoric qua practice. In explaining the cause of persuasion in any given instance (see discussion at 1355b9-11 and 1356a9-11), we will sometimes appeal to explanations from rhetoric qua faculty, the discipline that considers arguments and is dependent upon dialectic, and other times appeal to explanations relating to the facts from politics drawn upon by the orator. Similarly, I will argue that dialectic should be viewed as playing a role similar to the role played by geometry in explanations of optical phenomena. That is, as geometry is sometimes used to explain optical phenomena by looking at a restricted class of geometrical properties, so also a restricted class of argumentative modes from dialectic is applied to rhetorical situations.

\section{Rhetoric, Dialectic, and Politics}

Aristotle's description of rhetoric as "like an offshoot" (oíov $\pi \alpha \rho \alpha \varphi v \varepsilon$ c) of two distinct disciplines, dialectic and the part of politics concerned with character

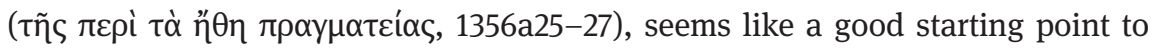
determine how he understands rhetoric's place. As Glenn Most (1994, 167)

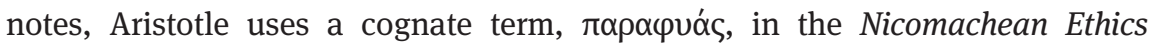
(1096a21). In EN, Aristotle uses the term to distinguish that which is per se from that which is secondary and accidental:

[...] but things are called good both in the category of substance and in that of quality and in that of relating, and that which is per se, i.e., substance, is prior in nature to the relative (for

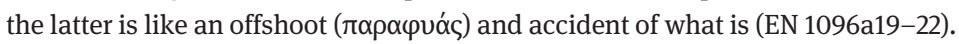

If we interpret Aristotle's use of "offshoot" in Rhet 1356a25 in light of this passage from EN, it seems that we should view "rhetoric as secondary and accidental" compared with dialectic (see Most 1994, 167). Understanding "offshoot" in this way supports the account I will provide of rhetoric's dependence upon dialectic.

15 For additional discussion, see Hankinson (2005, 38ff). 
Aristotle uses cognate terms to $\pi \alpha \rho \alpha \varphi v \varepsilon$ s in biological contexts such as the Historia Animalium (526a29-30) and the Parts of Animals (658a26-27), as well as

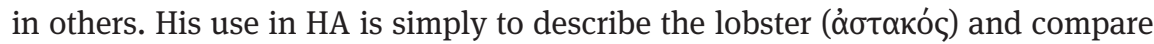

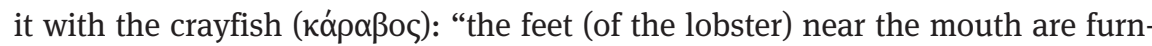
ished also with delicate appendages ( $\pi \alpha \rho \alpha \varphi v \alpha \dot{\delta} \alpha \varsigma)$.” This use of the cognate term $\pi \alpha \rho \alpha \varphi v \alpha \dot{\delta} \alpha \varsigma$ does not illuminate how Aristotle intends us to understand rhetoric's relation as an offshoot to dialectic and politics, nor does the use in PA. I suggest, then, that we look to his other discussions in the Rhetoric about how these disciplines are related to each other. In what remains of this section, I will first discuss rhetoric's relationship to dialectic, arguing that the type of arguments rhetoric uses (example and enthymeme) are instances of more widely used types of argument that Aristotle discusses under the rubric of dialectic. The rhetorician uses a restricted class of argument modes from dialectic because of the special context in which he uses them. The special context of rhetoric is one in which a speaker is addressing an audience that is unable to follow a long argument with many premises. Second, I will examine rhetoric's relationship to politics, arguing the following: first, that rhetoric qua practice is "under" politics insofar as it is used as a means in politics (agreeing with Cooper 1975 and McKirahan 1978); and second, that one uses facts from politics within rhetoric qua practice. This complexity makes the "under" relationship between rhetoric and politics different from the relationship between rhetoric and dialectic as well as different from the subalternate sciences model.

\subsection{Rhetoric and Dialectic}

Myles Burnyeat (1994) has argued against the traditional account of the enthymeme as simply a syllogism with one of its premises suppressed so that the members of an audience can fill it in themselves. He carefully traces how this doctrine has been repeated in numerous logic textbooks, and he argues that if this had been Aristotle's view of the enthymeme then it would be difficult to see why Aristotle saw it as so crucial for a rhetorician to know. That is, it would be difficult to see why Aristotle would have viewed enthymemes as the "body of

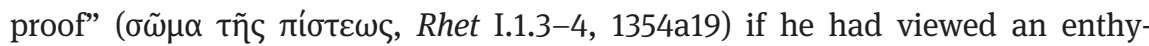
meme as merely a syllogism with a premise suppressed. As Burnyeat argues, it would be completely redundant to provide such an account of the enthymeme:

There is no more logical interest or utility in grouping together arguments that are incompletely expressed than there would be in grouping together arguments that are overelaborately expressed, or arguments that are obscurely or wittingly expressed" (Burnyeat 1994, 5). 
Why anyone would think that Aristotle would have placed so great an emphasis on such a redundancy, if this were his account, is a mystery.

Without discussing the details behind the traditional doctrine of the enthymeme and the finer details of Burnyeat's positive account of it, I will focus on what he has to say about the relationship between rhetoric and dialectic. Burnyeat suggests that we understand the difference between a dialectical and a rhetorical syllogismos to be related to the context in which they occur rather than to the character of their respective premises (Burnyeat 1994, 21). Since their difference is one of context, Burnyeat highlights several of the similarities between the two:

Both take their premises from endoxa, propositions that enjoy good repute, in the one case with people who require reasoned discussion, in the other with people who are accustomed to deliberation (Burnyeat 1994, 21).

Key among the differences that are dictated by context are the sorts of endoxa that the rhetorician should use compared with what the person engaging in dialectic should use. Aristotle discusses the sorts of endoxa the skilled rhetorician must use in Rhet II.22 and the differences in dialectical and rhetorical syllogismoi:

\footnotetext{
We have already said that the enthymeme is a kind of syllogism, what makes it so, and in what it differs from dialectical syllogisms; for the conclusion must neither be drawn from too far back nor should it include all the steps of the argument. In the first case its length causes obscurity, in the second, it is simply a waste of words, because it states much that is obvious. It is this that makes the ignorant more persuasive than the educated in the presence of crowds ... For the educated use commonplaces and generalities, whereas the ignorant speak of what they know and of what more clearly concerns the audience. Wherefore one must not speak from all possible opinions, but only from such as are definite and admitted, for instance, either by the judges themselves or by those of whose judgment they approve. Further, it should be clear that this is the opinion of all or most of the hearers (Rhet II.22, 1395b23-1396a4).
}

We can draw out a number of relevant points in this passage. First, the rhetorician should, as Burnyeat notes (1994, $21 \mathrm{fn}$.), work with a limited set of endoxa, namely, those that are "definite and admitted" rather than from all "possible opinions." Second, the rhetorician should not have too long an argument in his speech since the crowd will be unable to follow it. One might be tempted to read Aristotle's reference to the ignorant being more persuasive as supporting the view that the ignorant person is necessarily a better rhetorician, a view similar to Garver's (1988) view already criticized and the view we saw in the Gorgias. This passage does not, however, support such a view, for Aristotle's reference to the ignorant is designed only to justify restricting the range of endoxa from 
which enthymemes are drawn. If the educated person follows Aristotle's recommendation to restrict the endoxa upon which his enthymemes are based, then he will be persuasive - arguably more persuasive than the ignorant person.

This reading is consistent with what I argued earlier about how rhetoricians should treat particular subjects in their speeches (Rhet I.2.20, 1358a8-9). Specifically, Grimaldi's translation provides support: "the more they fasten upon the subject matter in its proper sense [ката̀ тро́тоv], the more they shift from the arts of rhetoric and dialectic" (Grimaldi 1980a, 73). Rhetoric, then, is distinguished by its unique context, both in the case of the "proper context" of the sciences as well from the context of dialectic.

If the primary difference between the rhetorical syllogism and a dialectical syllogism is one of context, then one can see why Aristotle describes rhetoric as both "composed of" and like an "offshoot" of dialectic and politics. The kinds of arguments in rhetoric - example and enthymeme - are simply special, restricted uses of the kinds of argument in dialectic because they are used in a specific, narrow context. This reliance of the faculty of rhetoric - rhetoric qua faculty - upon dialectic partly resembles the way in which geometrical principles are used to explain optical phenomena. For example, in explaining any particular instance of persuasion, i.e., in seeking the cause for why a particular speech was persuasive, one will need to appeal to dialectic insofar as the speaker used either enthymemes or examples in the speech. It may seem strange to think of explanation being involved in this context since, as a $\tau \dot{x} \chi v \eta$, rhetoric has the goal of persuasion and not explanation. However, it is important to note that as a faculty or skill which is acquired, to learn rhetoric qua faculty we must appeal to a cause of persuasion (see 1355b9-11; 1356a9-11) and one such cause may be that the rhetor employed an enthymeme. So as a skilled rhetor teaching rhetoric qua faculty to a group of would-be rhetors, I must borrow, like in the case of geometry and optics, when I show them that a given speech was persuasive because it used an enthymeme. In other words, in this context the borrowing of argumentative forms functions like borrowing a cause when explaining an instance of persuasion to those who hope to acquire the skill of rhetoric.

As I mentioned at the outset of the paper, I do not claim that Aristotle viewed rhetoric as a subalternate science but only that thinking about the relationship between rhetoric and dialectic and politics in light of the subalternate sciences is useful. My goal is to outline some similarities between the dialecticrhetoric relationship and the geometry-optics relationship, with the caveat that, even with these similarities, at the heart there are differences between $\tau \dot{c} \chi v \alpha$, such as dialectic and rhetoric, and the subalternate science of optics and the science of geometry. Although in some circumstances it may be appropriate to 
explain the cause of persuasion, such as when teaching rhetoric qua faculty, in large part explanation is not the goal of rhetoric.

We can provide a similar account for 'example' as we did for enthymeme,

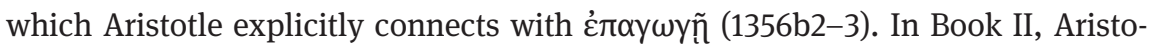
tle again connects the two, arguing that "example ( $\pi \alpha \rho \alpha \delta \varepsilon เ \gamma \mu \alpha)$ resembles in-

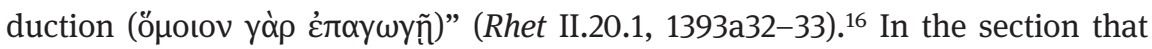
follows, Aristotle provides instances of the two kinds of example, the first relating to examples of something that has already happened and the other relating to examples that one makes (логеiv) (1393a34-36). Although Aristotle does not provide extended discussion of how an example is a kind of $\varepsilon \pi \alpha y \omega y \tilde{n}$ here, from the specific instances of example that he provides in 1393a36-1394a12 it is clear that an example in rhetoric moves from a claim about one particular to a claim about another particular.

Thus, if one wants to persuade a crowd that "it is necessary to make preparations against the Great King and not allow him to subdue Egypt," Aristotle says that one should appeal to the historical example of Darius or to the example of Xerxes (1393a38-1393b6). Examples are not to be, however, the rhetorician's first choice when constructing a speech. One should use an example if he does not have an enthymeme available, or if he has enthymemes to support his case he should use examples as supporting evidence (literally as "testimonies," $\mu \alpha$ ртupíoı) for them (1394a13-18). Though there is some debate over Aristotle's account of $\dot{\varepsilon} \pi \alpha \omega y \tilde{n}$ (see Smith 1995), most would agree that it involves making a move from a claim about some particular or particulars to a claim that is more general or universal.

With this in mind, we can view 'example' as a restricted use of '̇ं $\alpha y \omega y \tilde{n}$, especially since examples move from particular to particular (1357b25ff). Given this difference in moving from particular to universal (induction) and particular

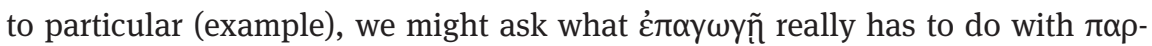

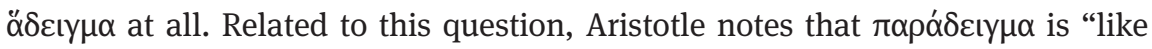

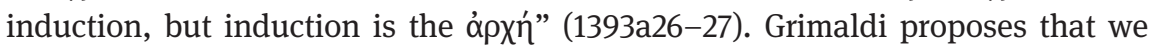
understand ópx'́ as suggesting that "one cannot use example without explicitly or implicitly making a real induction to apprehend the general class under which the example falls" (1980b, 250; see also 1980a, 69 for discussion regarding 1357b27). So in using an example as a restricted form of induction, one skips over the steps of an induction and makes a leap from a particular, which is better known, to another particular, which less well known. This restricted and

16 See also APo I.1 where Aristotle notes that "The means by which rhetorical arguments carry conviction are just the same; for they use either examples, which are a kind of induction (غं $\pi$ -

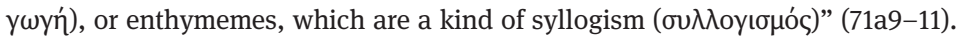


limited use is due to the difference in context, especially since a crowd will be unable to follow a longer form of argument (for additional discussion, see McAdon 2001, 142).

If this understanding of rhetoric's relation to dialectic is on the right track, what implications does this have for our understanding of Aristotle's claim that rhetoric is a "counterpart" to dialectic (Rhet I.1.1, 1354a1)? I suggest that when discussing the status of rhetoric as a "counterpart," it seems that Aristotle is talking about rhetoric qua faculty. If this is how Aristotle is using 'rhetoric' there, then perhaps we should understand this aspect of rhetoric as "convertible" (see fn. 8) to a restricted part of dialectic. That is, perhaps we should take

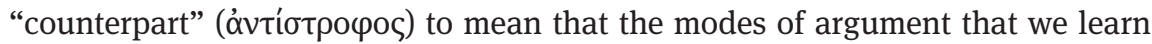
as students of rhetoric and that are written about by writers of rhetorical handbooks are simply convertible to what we would find in a work about dialectic.

\subsection{Rhetoric and Politics}

In this section, I will suggest that the "under" relationship between rhetoric and politics differs from what we find in the subalternate sciences model; as a result, the "under" that we find between rhetoric and politics differs from what we find between rhetoric and dialectic. As others have noted, rhetoric is under politics because it is used in service of the aims of politics (Cooper 1975; McKirahan 1978). Here the discipline that is "under" (rhetoric) is used in the service of the discipline that is "over" (politics). However, other commentators have not highlighted the extent to which Aristotle stresses that the skilled rhetorician must be knowledgeable about the polis if he is to be successful at rhetoric qua practice. In the section immediately following one of the passages on boundary crossing (Rhet I.4.5-7, 1359b9-16), Aristotle provides an extended discussion of all the things that the skilled rhetorician, specifically in this context the individual who will be successful in deliberative oratory, will need to know (Rhet I.4.7-13, 1359b19-1360b3). ${ }^{17}$ Aristotle begins this passage as follows: "Nevertheless, even at present we may mention such matters as it is worthwhile to analyze, and yet leave an investigation to political science ( (1359b19-21). Similarly, at the close of Rhet I.8, he notes that the discussion of these matters has been "...to the extent demanded by the present occasion; a

17 In addition, Aristotle claims that "The most important and effective qualifications for success in persuading audiences and speaking well on public affairs is to understand all the forms of government and to discriminate their respective customs, institutions, and interests (Rhet I.8 1365b22-25). 
detailed account of the subject has been given in the Politics" (1366a21). The other two divisions of oratory, i.e., forensic and epideictic, will rely similarly upon politics, for they differ from epideictic oratory only with respect to "different kinds of time" (1358b13-15). Whereas the deliberative orator is concerned with the future, the forensic orator is concerned with the past and the epideictic orator is concerned with the present (1358b14ff).

In these discussions, Aristotle seems again to distinguish between the work of rhetoric qua faculty as something that considers arguments alone (1359b16) and rhetoric qua practice that must draw upon the work of politics. In the practice of rhetoric, the rhetor must know the subjects that Aristotle discusses in the sections that follow, topics from political science: ways and means, war and peace, national defense, imports and exports, and legislation (see Rhet I.4.7-13, 1359b19-1360b3). For each of these subjects, Aristotle stresses repeatedly that

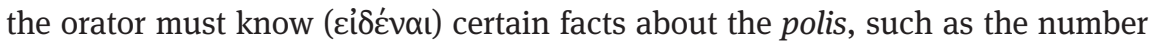
and extent of the country's sources of revenue (1359b24-25).

Having recited these things that the would-be orator needs to know, Aristotle states that, even though such an orator must know them, all these things belong

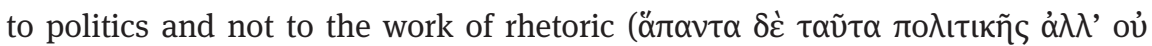

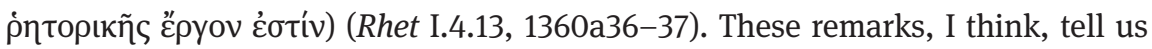
two things about Aristotle's view of rhetoric's relationship to politics. First, rhetoric qua faculty, something that is written about and learned by students, is not concerned with facts from political science but only with arguments (as 1359b16 advises). Second, even though students do not focus on learning facts from political science when being trained as a rhetoricians, when they are engaged in rhetoric - rhetoric qua practice - they must know these facts and use them when giving speeches. This relationship that Aristotle asserts between rhetoric qua practice and politics, I argue, is part of his response to Plato's criticism of rhetoric in Gorgias (458e-459c). There Socrates criticizes rhetoric because it lacks substantive knowledge since it could be applied to any topic whatsoever. On Aristotle's account, however, rhetoric borrows its facts from the science of politics. This type of "over" and "under" relationship is different from what we have found in the subalternate sciences. Between rhetoric qua practice and politics, there is no sameness of genera that legitimizes the borrowing that occurs; nevertheless one borrows facts from politics as is suitable for making a persuasive speech. The relationship between rhetoric and politics is thus somewhat complex. On the one hand, rhetoric is used in the service of the aims of politics, but on the other hand, rhetoric qua practice must itself borrow facts from politics.

Further things that the successful orator must know relate to the various emotions that are likely to aid him in persuading a crowd; indeed, a large portion of Rhet Book II is concerned with the emotions. The reason why the suc- 
cessful orator must know about the emotions is because "the object of rhetoric is judgment" and to convince someone to make a particular judgment "it is not only necessary to consider how to make the speech itself demonstrative and convincing, but also that the speaker should show himself to be of a certain character and should know how to put the judge in a certain frame of mind" (Rhet II.1.1, 1377b20-29). I take it that the first component, i.e., making a speech "demonstrative and convincing," is what has already been discussed in the present paper as we have reflected upon Book I. Discussing the second component, however, is beyond the bounds of the present discussion, but it demonstrates yet another way in which the practice of rhetoric depends upon facts from another discipline.

\section{Conclusion}

I have argued that distinguishing between rhetoric as what the orator does in practice and rhetoric as a faculty that people writing handbooks on rhetoric and students learning rhetoric focus upon dissolves some of the difficulties introduced by Garver's (1988) interpretation (also Allen 2007). Aristotle's account of rhetoric is not only that it is "under" politics, as Cooper (1975) and McKirahan (1978) have noted, but also that the practicing rhetorician uses facts from politics, though he does so in a way different from how he would use them within that discipline. These facts are still the "work" of politics, though, and not of rhetoric. Finally, I have argued that the modes of argument used in rhetoric are a restricted class of those used in dialectic; they are restricted given the differences in the context of dialectic and the context of rhetoric. Future work on this topic might consider the role that knowledge of the emotions plays and how this is related to the work of rhetoric qua faculty and qua practice.

Acknowledgements: I wish to thank James Lennox for extensive feedback on a previous draft of this paper. I also thank David deSilva for our discussions of the Rhetoric.

\section{References}

Aristotle. 1926. The Art of Rhetoric. John Henry Freese, trans. and ed. London: Putnam and Sons. 
Aristotle. 1991. On Rhetoric: A Theory of Civic Discourse. George Kennedy, trans. New York: OUP.

Aristotle. 1984. The Complete Works of Aristotle. Volume II. Jonathan Barnes, trans. and ed. Princeton: Princeton University Press.

Allen, James. 2007. "Aristotle on the Disciplines of Argument: Rhetoric, Dialectic, Analytic." Rhetorica 25.1: 87-108.

Cooper, John M. 1975. Reason and Human Good in Aristotle. Cambridge, MA: Harvard University Press.

Barnes, Jonathan. 1975. Aristotle's Posterior Analytics. Oxford: Clarendon Press, 1975.

Burnyeat, M. F. 1994. "Enthymeme: Aristotle on the Logic of Persuasion." In Aristotle's Rhetoric, David J. Furley and Alexander Nehamas, eds. Princeton, NJ: Princeton University Press, 3-56.

Garver, Eugene. 1988. "Aristotle's Rhetoric on Unintentionally Hitting the Principles of the Sciences.” Rhetorica 6.4: 381-393.

Green, Lawrence D. 1990. “Aristotelian Rhetoric, Dialectic, and the Traditions of 'Avtíotpoфоৎ.” Rhetorica 8.1: 5-27.

Grimaldi, William M. A. 1980a. Aristotle, Rhetoric I: A Commentary. New York: Fordham University Press.

Grimaldi, William M. A. 1980b. Aristotle, Rhetoric II: A Commentary. New York: Fordham University Press.

Haskins, Ekaterina. 2013. “On the Term 'Dunamis' in Aristotle’s Definition of Rhetoric.” Philosophy and Rhetoric 46.2: 234-240.

Hankinson, R.J. 2005. "Aristotle on Kind-Crossing." In R.W. Sharples, ed., Philosophy and the Sciences in Antiquity. Aldershot: Ashgate Publishing Limited, 23-54.

Johnstone, Christopher Lyle. 1980. "An Aristotelian Trilogy: Ethics, Rhetoric, Politics, and the Search for Moral Truth." Philosophy and Rhetoric 13.1: 1-24.

Kassel, Rudolfus, ed. 1976. Aristoteles Ars Rhetorica. Berlin: Walter de Gruyter.

Kennedy, George A. 1991. Aristotle On Rhetoric, second ed., 2007. Oxford: Oxford University Press.

Laird, Walter R. 1983. The Scientiae Mediae in Medieval Commentaries on Aristotle's Posterior Analytics. University of Toronto: Ph.D. Dissertation.

Lennox, James G. 1986. “Aristotle, Galileo, and the 'Mixed Sciences'." In Reinterpreting Galileo, William A. Wallace, ed. Washington, DC: Catholic University Press, 29-51.

Lennox, James G. 2005. “The Place of Zoology in Aristotle's Natural Philosophy.” In R.W. Sharples, Philosophy and the Sciences in Antiquity, ed. Aldershot: Ashgate Publishing, 55-71.

Lindberg, David C. 1996. Roger Bacon and the Origins of Perspectiva in the Middle Ages. Oxford: Clarendon Press.

Livesey, Steven J. 1982. Metabasis: The Interrelationship of the Sciences in Antiquity and the Middle Ages. University of Toronto: Ph.D. Dissertation.

Livesey, Steven J. 1985. "William of Ockham, the Subalternate Sciences, and Aristotle's Theory of metabasis." British Journal for the History of Science 18: 127-145.

McAdon, Brad. 2001. "Rhetoric is a Counterpart to Dialectic." Philosophy and Rhetoric 34.2: $113-150$.

McKirahan, Richard D. 1978. "Aristotle's Subordinate Sciences." British Journal for the History of Science 11: 197-220.

McKirahan, Richard D. 1992. Principles and Proofs: Aristotle's Theory of Demonstrative Science. Princeton, NJ: Princeton University Press. 
Plato. 1998. Gorgias and Phaedrus. James H. Nichols, trans. Ithaca: Cornell University Press. Plato. 1990. Gorgias. E.H. Dodds, trans. Oxford: Clarendon Press.

Roberts, W. Rhys. 1924. "References to Plato in Aristotle's Rhetoric." Classical Philology 19: 342-346.

Ross, W. D. 1949. Aristotle's Prior and Posterior Analytics. Oxford: Clarendon Press.

Rowland, Robert C. and Deanna F. Womack. 1985. "Aristotle's View of Ethical Rhetoric." Rhetoric Society Quarterly 15: 13-31.

Smith, Robin. 1995. "Logic." In Jonathan Barnes, The Cambridge Companion to Aristotle. Cambridge: Cambridge University Press, 27-65. 